\title{
Body composition and hypertension: A comparative study involving women from maroon communities and from the general population of Alagoas State, Brazil ${ }^{1}$
}

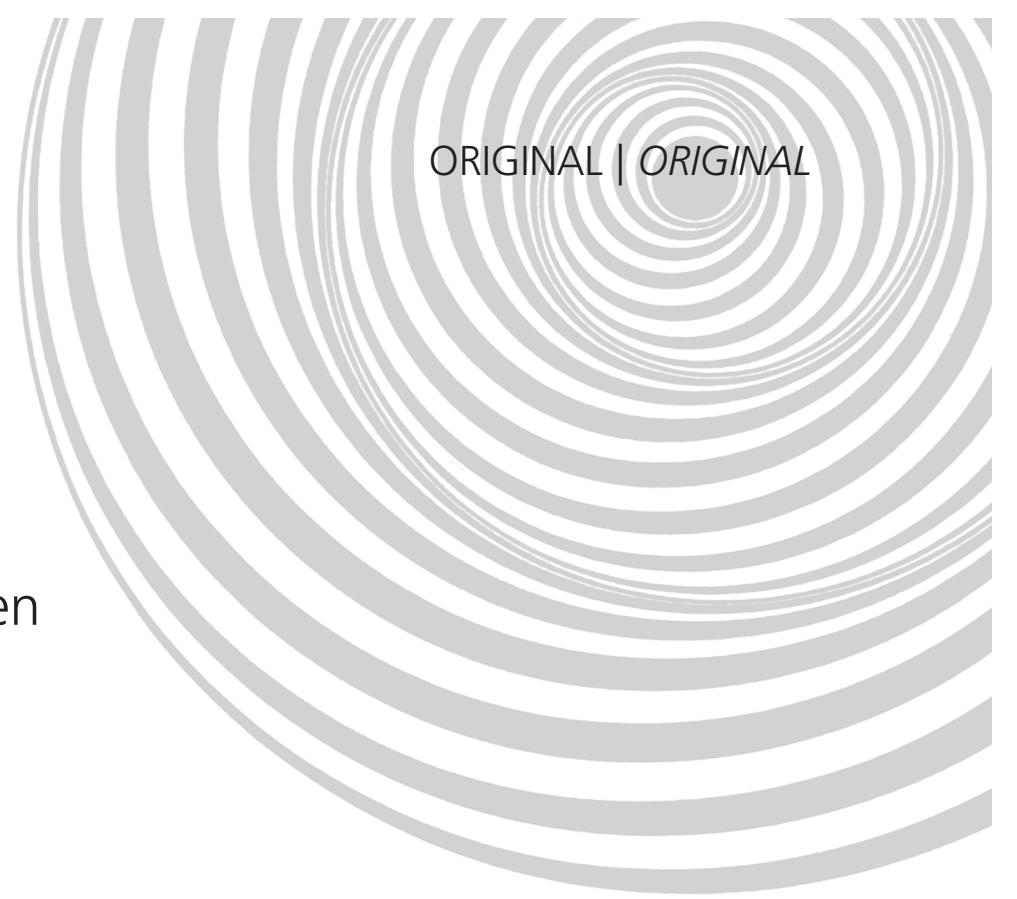

\author{
Composição corporal e hipertensão arterial: \\ estudo comparativo envolvendo mulheres \\ das comunidades quilombolas e da \\ população geral de Alagoas, Brasil
}

\author{
Haroldo da Silva FERREIRA ${ }^{2}$ \\ Wcleuton Oliveira SILVA ${ }^{3}$ \\ Ewerton Amorim dos SANTOS 3 \\ Myrtis Katille de Assunção BEZERRA ${ }^{3}$ \\ Bárbara Coelho Vieira da SILVA ${ }^{3}$ \\ Bernardo Lessa HORTA ${ }^{4}$
}

A B S T R A C T

\section{Objective}

This study investigated the body composition and prevalence of hypertension in maroon women from the State of Alagoas and compared these variables with those of non-maroon women from the same state.

\section{Methods}

The data were collected from two cross-sectional surveys done in 2005 and 2008. The first study included a representative sample of mothers of children aged 0 to 5 years from the State of Alagoas, and the second study

1 Article based on the dissertation of WO SILVA, intitled "Estado nutricional e fatores de risco em mulheres adultas: um estudo comparativo com descendentes quilombolas e a população do Estado de Alagoas, Brasil". Universidade Federal de Alagoas; 2010.

2 Universidade Federal de Alagoas, Faculdade de Nutrição. Campus A.C. Simões, BR 104 Norte, Km 96.7, Tabuleiro do Martins, 57072-970, Maceió, AL, Brasil. Correspondência para/Correspondence to: HS FERREIRA. E-mail: <haroldo.ufal@gmail.com>.

3 Universidade Federal de Alagoas, Faculdade de Nutrição, Programa de Pós-Graduação em Nutrição. Maceió, AL, Brasil.

${ }^{4}$ Universidade Federal de Pelotas, Centro de Pesquisas Epidemiológicas, Programa de Pós-Graduação em Epidemiologia. Pelotas, Rio Grande do Sul, Brasil.

Apoio: Conselho Nacional de Desenvolvimento Científico e Tecnológico (Processo nº 478607/2007-5). 
540 | HS FERREIRA et al.

included all women aged 18 to 60 years living in maroon communities $(n=39)$ in the same state. Data were collected during home interviews. The prevalence ratio and respective $95 \%$ confidence interval given by the Poisson regression with robust adjustment of variance was used as the measure of association.

\section{Results}

The study assessed 1,631 maroon women and 1,098 non-maroon mothers. Maroon women had lower education level, more children, higher prevalence of hypertension and stunting, and higher age at menarche, body mass index, waist circumference, waist-to-height ratio, and waist-to-hip ratio. After adjustment for age, the following prevalences remained higher in maroon women: hypertension ( $P R=1.81 ; 95 \% \mathrm{Cl}: 1.49 ; 2.21), W C \geq 80 \mathrm{~cm}$ $(P R=1.2395 \% C l: 1.11 ; 1.37), W H t R>0.5(P R=1.11 ; 95 \% C l: 1.02 ; 1.21)$, and $W H R \geq 0.85(P R=1.64 ; 95 \% C l:$ $1.43 ; 1.88)$.

\section{Conclusion}

Maroon women belong to lower socioeconomic classes than non-maroon women and are at greater risk of abdominal obesity and hypertension, characteristics that make them especially vulnerable to the morbidity and mortality caused by cardiovascular diseases, justifying the preferential implementation of measures of care.

Indexing terms: Anthropometry. Health of specific groups. Nutrition transition. Nutritional status. Overweight.

\section{R E S U M O}

\section{Objetivo}

Investigar, no âmbito do Estado de Alagoas, a composição corporal e a prevalência de hipertensão arterial em mulheres quilombolas, tendo como referencial mulheres não quilombolas.

\section{Métodos}

Os dados procedem de dois inquéritos transversais realizados em 2005 e 2008. O primeiro estudou amostra representativa de mães e crianças menores de cinco anos de Alagoas. Para o segundo, eram elegíveis todas as mulheres de 18 a 60 anos residentes nas comunidades $(n=39)$ quilombolas do estado. As informações de interesse foram obtidas por meio de visitas domiciliares. Utilizaram-se como medida de associação a razão de prevalência e o respectivo intervalo de confiança de 95\%, calculados por análise de regressão de Poisson com ajuste robusto da variância.

\section{Resultados}

Foram avaliadas 1631 mulheres quilombolas e 1098 não quilombolas. As mulheres quilombolas apresentaram menor escolaridade, maior número de filhos, maior prevalência de hipertensão arterial, menor estatura, maior idade da menarca, maior índice de massa corporal, bem como percentual de gordura corporal, circunferência da cintura, razão entre cintura e estatura e razão entre cintura e quadril. Após ajuste para idade, as prevalências das seguintes condições permaneceram mais elevadas entre quilombolas: hipertensão arterial (RP=1,81; IC95\%: 1,49; 2,21), circunferência da cintura $\geq 80 \mathrm{~cm}$ (razão de prevalência $=1,23$ IC95\%: 1,11; 1,37), $R C E>0,5(R P=1,11$; IC95\%: 1,02; 1,21) e $R C Q \geq 0,85$ ( $R P=1,64$; IC95\%: 1,43; 1,88).

\section{Conclusão}

O nível socioeconômico das mulheres quilombolas é inferior ao das não quilombolas; além disso, as quilombolas estão submetidas a um maior risco de obesidade abdominal e de hipertensão arterial, características que as classificam como um grupo especialmente vulnerável à morbimortalidade por doenças cardiovasculares, justificando prioridade na implementação de medidas de atenção.

Termos de indexação: Antropometria. Saúde de grupos específicos. Transição nutricional. Estado nutricional. Sobrepeso.

\section{INTRODUCTION}

The high prevalence of obesity in populations from developed countries has long been a reason for concern. However, in the last years, the prevalence of excess weight has also increased in populations from developing countries $^{1,2}$.

Some authors ${ }^{3,4}$ consider that this phenomenon reflects the dynamics of nutritional 
transition combined with a complex epidemiological scenario resulting from the rapid urbanization that occurred in the last decades, low levels of physical activity, and excessive energy intake. In countries such as Brazil, these events have been associated with a high prevalence of chronic non-communicable diseases ${ }^{3,5}$, which coexist with infectious diseases and specific nutritional deficiencies.

The introduction of public policies focusing on the prevention and treatment of health hazards resultant from this scenario depends on the systematic monitoring of the current situation. Accordingly, many population surveys have been done in Brazil, evidencing important increases in the prevalence of excess weight in the general population and particularly in women from the Brazilian Northeast and the lower-income classes ${ }^{6-8}$.

According to the Institute of Applied Economic Research ${ }^{9}$, the Brazilian Northeast has the highest poverty rates of the federation, and the State of Alagoas stands out with the worst social indicators ${ }^{10}$.

According to a national survey covering the five Brazilian macroregions ${ }^{6}$, excess weight was most prevalent in African Brazilians and biracial women, and these two groups belong to the lowest socioeconomic strata of the country.

Some studies have shown that women of African descent are more susceptible to central obesity ${ }^{11,12}$, a condition that is strongly associated with chronic non-communicable diseases, such as hypertension ${ }^{13}$.

A large portion of the African-Brazilian population still lives in maroon communities, known as quilombos ${ }^{14}$. Quilombo refers to any rural African-Brazilian community, that is, a maroon community consisting of slave descendants who make their living from subsistence agriculture and where cultural manifestations are strongly connected to the history of their ancestors ${ }^{15}$. Individuals from these communities are known as quilombolas.

According to the Chamada Nutricional Quilombola, done in $2006^{16}$, most individuals from these communities belong to the classes E or D, are illiterate, and live in very poor environmental and sanitary conditions.

In 2008, there were 39 maroon communities in Alagoas enrolled in the state program Management of Maroon Programs (Gerência de Programas Afros-quilombolas). No other epidemiological study to date has focused specifically on this population.

Given that African-Brazilian women require special attention because of their greater social and biological vulnerability ${ }^{17}$ and that this attention depends on diagnosing the current situation, the objective of the present study was to investigate the body composition of and prevalence of hypertension in women from maroon communities in the State of Alagoas and compare them with those of women from the general population of Alagoas.

\section{METHOD S}

The data were extracted from two population-based cross-sectional studies. The first study originated from a project called "Nutritional diagnosis and health of maroons from the State of Alagoas" (Diagnóstico de nutrição e saúde da população remanescente dos quilombos do Estado de Alagoas) that included all women aged 18.0 to 59.9 years from the 39 maroon communities in the State (according to 2008 records of the Alagoas government). The second study originated from a survey called "Diagnosis of mother-infant health in the State of Alagoas" (Diagnóstico de saúde materno-infantil do Estado de Alagoas) that included a representative sample of mothers of children aged 0 to 5 years. Further information about these studies' sampling methods can be found in Ferreira et al. ${ }^{18}$ and Ferreira \& Luciano ${ }^{19}$, respectively. Henceforth, these studies will be referred to as "maroon survey" and "state survey."

The maroon survey was done from July to November 2008 and the state survey from September 2005 to February 2006. 
Blood pressure was taken by an auto inflate blood pressure monitor (Omron ${ }^{\circledR}$, model HEM 705 CP), calibrated first by the manufacturer and then weekly during the field work by comparing the results with those obtained by a mercury sphygmomanometer used specifically for this purpose. Blood pressure was taken with the individual sitting down after emptying her bladder and resting for 15 minutes. Two measurements were taken two minutes apart. The cuff was placed two centimeters above the antecubital fossa, centered on the brachial artery of the left upper arm. If the systolic blood pressures differed by more than $5 \mathrm{mmHg}$, a third measurement was taken and the most discrepant measure was discarded. The mean of two valid measurements was used for the analyses. Women with a Systolic Blood Pressure (SBP) $\geq 14 \mathrm{mmHg}$ and/or a Diastolic Blood Pressure (DBP) $\geq 90 \mathrm{mmHg}$, and those on antihypertensives were considered hypertensive ${ }^{20}$.

The anthropometric data were collected by two trained and supervised anthropometrists. The measurements in both surveys were done as recommended by Lohman et al. ${ }^{21}$. The participants were weighed by a digital scale (Marte ${ }^{\circledR}$ PP 180) with a capacity of $180 \mathrm{~kg}$ and accuracy of $100 \mathrm{~g}$, the maximum amount in which two measurements were allowed to differ. Height was determined by the portable stadiometer Seca ${ }^{\circledR}$ mounted on a wooden board. This stadiometer uses an inflexible 2-meter tape measure with an accuracy of $0.1 \mathrm{~cm}$. The participants were asked to remove their decorative objects and measured standing barefoot with their heads in the Frankfort plane. Two measurements were allowed to differ by a maximum of $0.5 \mathrm{~cm}$. When the measured weights or heights exceeded the maximum tolerated differences, a third measurement was taken, discarding the most discrepant measurement and using the mean of the other two. Pregnant women and those with other anatomical changes were excluded from the analyses.

A participant was considered stunted if her height-for-age was two or more standard deviations below the mean (Z-score <-2) of 19-year-old women given by the World Health Organization $(\mathrm{WHO})^{22}$. Hence, women measuring less than $150.1 \mathrm{~cm}$ were considered stunted.

An inflexible tape measure of the brand Sanny ${ }^{\circledR}$ was used for taking the circumferences. Waist Circumference (WC) was measured at the narrowest point between the lowest rib and the iliac crest, while Hip Circumference (HC) was measured at the point of maximum circumference of the buttocks. The cut-off points used for diagnosing abdominal fat were waist circumference $\geq 80.0 \mathrm{~cm}$ and Waist-To-Hip (WTH) ratio $\geq 0.85^{23}$. The ratio between WC and height (WHtR) in $\mathrm{cm}$ was also used. In this case, the cut-off point was $>0.5^{24}$.

The women were classified as underweight (<18.5), normal weight (18.5 to 24.9), overweight (25.0 to 29.9 ) or obese $(\geq 30)$ according to their Body Mass Index $\left(B M I=k g / \mathrm{m}^{2}\right)^{23}$.

The percentage of body fat was estimated by bioelectrical impedance analysis using the Omron ${ }^{\circledR}$ Body Fat Analyzer, model HBF-306. Nutritional status was classified as follows ${ }^{25}$ : underweight (up to $16.0 \%$ of body fat), normal weight (16.1\% to $25.0 \%$ ), excessive weight (25.1\% to $33.0 \%$ ) and tending towards obesity (>33.0\%).

The maroons' economic class was determined by the Brazilian Economic Classification Criterion ${ }^{26}$, which consists of attributing points to the ownership of certain items such as television set, radio, bathroom, car, and refrigerator, among others, and to the education level of the family head. The economic class (A1, $A 2, B 1, B 2, C 1, C 2, D$ and $E$ ) of an individual will be given by the total score, which increases with class. Since there were no individuals from class $A$ and few from the classes $B$ and $C$, the participants were divided into two groups: classes $\mathrm{D}+\mathrm{E}$; and other classes.

The means were compared by the MannWhitney $U$ test for independent samples since most variables were nonparametric according to the Stata ${ }^{\circledR}$ sktest that tested for kurtosis and 
skewness. The Pearson's chi-square test $\left(\chi^{2}\right)$ was used for comparing proportions. The Prevalence Ratio (PR) and respective Confidence Interval $(95 \% \mathrm{Cl})$, given by the Poisson regression with robust error variance were used as measures of association. This procedure was repeated for all study variables to compare the two surveys. In addition to the crude analyses, the estimates were also adjusted for age.

The two surveys were approved by the Research Ethics Committee of the Universidade Federal de Alagoas (Protocol numbers 010102/ 2003-35 and 022355/2008-66). All women who agreed to participate in the study signed a Free and Informed Consent Form.

\section{RESULTS}

A total of 1,631 women from maroon communities and 1,098 mothers of children younger than 5 years from the general population of Alagoas were studied. Most (91.9\%) maroons belonged to the economic classes $E$ and $D$. Low education level ( $\leq 3$ years of formal education) was also more common in maroons ( $52.7 \%$ vs. $33.2 \%$; $\mathrm{PR}=1.59 ; 95 \% \mathrm{Cl}=1.44 ; 1.75)$, who also had more children (4.6 vs. $2.7 ; p<0.001)$. Most maroon mothers (66.4\%) had more than 2 children while only $33.2 \%$ of those from the state survey had more than 2 children $(P R=2.0 ; 95 \% \mathrm{Cl}=1.81$; 2.22).

The prevalences of overweight and obesity were higher than the prevalences of underweight, both in maroons and in women from the state survey (Figure 1), and the prevalence of underweight in women from the state survey was higher than that in maroons $(5.1 \%$ vs. $3.1 \% ; p=0.007)$. On the other hand, the prevalence of overweight and obesity in maroons was higher than that for women from the state survey (50.1 vs. 44.2; $p=0.002$ ). Similar results were observed for the percentage of body fat (Table 1).

The waist-to-height ratio (Figure 2) was the central adiposity indicator that most often exceeded the cut-off point: $61.1 \%$ of maroons and $44.3 \%$ of the mothers from the state survey had high WHtR (PR=1.38; $95 \% \mathrm{Cl}=1.28 ; 1.49)$.

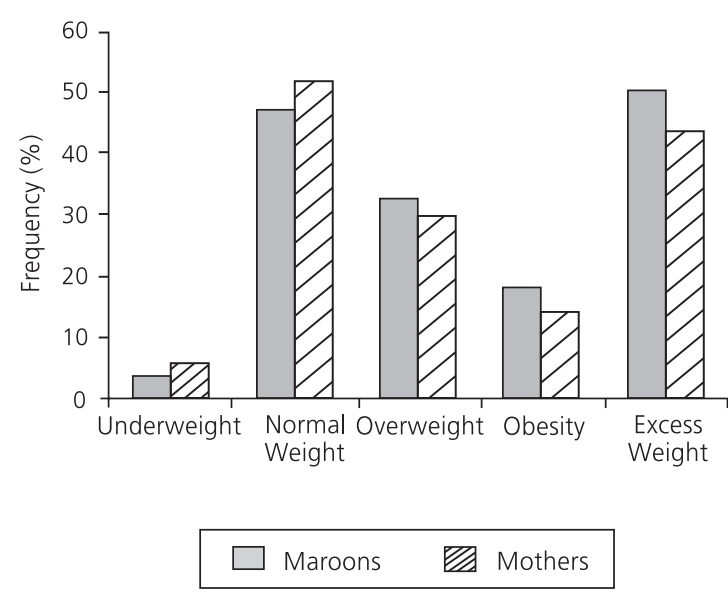

Figure 1. Distribution of maroon women (2008) and mothers of children aged 0 to 5 years (2005) according to their body mass index classification. Alagoas, Brazil.

Note: "Statistically significant difference $(p<0.05)$; Excess weight=overweight+obesity.

Table 1. Distribution of maroon women (2008) and mothers of children aged 0 to 5 years (2005) according to their percentage of body fat determined by bioelectrical impedance analysis. Alagoas, Brazil.

\begin{tabular}{|c|c|c|c|c|c|c|}
\hline \multirow[b]{2}{*}{ Classification } & \multicolumn{2}{|c|}{ Maroons } & \multicolumn{2}{|c|}{ Mothers } & \multirow{2}{*}{ Prevalence ratio $(95 \% \mathrm{Cl})$} & \multirow{2}{*}{$p^{*}$} \\
\hline & $\mathrm{n}$ & $\%$ & $\mathrm{n}$ & $\%$ & & \\
\hline Underweight (<16.0\%) & 62 & 3.9 & 36 & 7.6 & $0.70(0.48 ; 1.02)$ & \\
\hline Normal weight (16.0\% a $25.0 \%$ ) & 376 & 23.7 & 143 & 30.2 & Reference & \\
\hline Overweight (25.1\% a $33.0 \%)$ & 559 & 35.3 & 184 & 38.9 & $1.06(0.95 ; 1.18)$ & $<0.001$ \\
\hline Obese $(>33.0 \%)$ & 587 & 37.1 & 110 & 23.3 & $1.40(1.20 ; 1.63)$ & \\
\hline Total & 1,584 & 100.0 & 473 & 100.0 & - & \\
\hline
\end{tabular}

Note: ${ }^{*}$ Chi-square test for linear tendency. $95 \% \mathrm{Cl}$ : Confidence Interval of 95\%. 


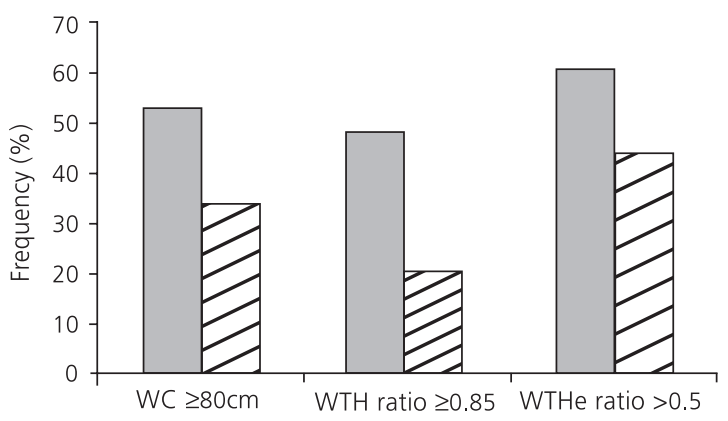

Figure 2. Distribution of abdominal obesity indicators of maroon women (2008) and mothers of children aged 0 to 5 years (2005). Alagoas, Brazil.

Note: "Statistically significant difference $(p<0.05)$.

WC: Waist Circumference; WHR: Waist-to-Hip; WTHe: Waist-to-Height.
Table 2 shows the medians of the study variables for the maroons and women from the state survey. Maroons were older, shorter, and heavier, and had higher age at menarche, systolic and diastolic blood pressures, body mass index, waist circumference, WHR, and WHtR.

The crude data shows that the following conditions were more prevalent in maroons than in women from the state survey $(p<0.05)$ : stunting, age at menarche $\geq 13$ years, $\mathrm{BMI} \geq 25 \mathrm{~kg} / \mathrm{m}^{2}$, hypertension, percentage of body fat $>33 \%$, WC $\geq 80 \mathrm{~cm}, W H t R>0.5$, and WHR $\geq 0.85$ (Table 3 ).

Table 2 also shows that maroons were significantly older than the women from the state survey. Therefore, this variable needed adjustment,

Table 2. Age, blood pressure, and anthropometric characteristics of maroon women (2008) and mothers of children aged 0 to 5 years (2005). Alagoas, Brazil.

\begin{tabular}{|c|c|c|c|c|c|}
\hline \multirow{2}{*}{ Variables } & \multicolumn{2}{|r|}{ Maroons } & \multicolumn{2}{|r|}{ Mothers } & \multirow{2}{*}{$p^{*}$} \\
\hline & $\mathrm{n}$ & Median (P25; P75) [95\%Cl] & $n$ & Median (P25; P75) [95\%CI] & \\
\hline Age (years) & 1,631 & $\begin{array}{c}34.0(26.0 ; 44.0) \\
{[34.9 ; 36.0]}\end{array}$ & 1,079 & $\begin{array}{c}27.0(23.0 ; 32.0) \\
{[27.4 ; 28.2]}\end{array}$ & $<0.001$ \\
\hline Weight (kg) & 1,631 & $\begin{array}{c}60.5(53.1 ; 69.0) \\
{[61.3 ; 62.4]}\end{array}$ & 1,096 & $\begin{array}{c}58.7(51.8 ; 67.5) \\
{[59.9 ; 61.4]}\end{array}$ & 0.002 \\
\hline Height (cm) & 1,629 & $\begin{array}{c}155.3(151.0 ; 159.3) \\
{[155.1 ; 155.6]}\end{array}$ & 1,098 & $\begin{array}{c}155.5(152.1 ; 159.6) \\
{[155.5 ; 156.2]}\end{array}$ & 0.019 \\
\hline Sitting height $(\mathrm{cm})$ & 1,615 & $\begin{array}{c}81.1(78.8 ; 83.2) \\
{[80.5 ; 81.0]}\end{array}$ & 475 & $\begin{array}{c}81.9(79.6 ; 84.4) \\
{[81.2 ; 82.2]}\end{array}$ & $<0.001$ \\
\hline Age at menarche (years) & 1,550 & $\begin{array}{c}13.0(12.0 ; 14.0) \\
{[13.1 ; 13.3]}\end{array}$ & 1,013 & $\begin{array}{c}13.0(12.0 ; 14.0) \\
{[12.8 ; 12.9]}\end{array}$ & $<0.001$ \\
\hline Systolic blood pressure & 1,613 & $\begin{array}{c}125.5(115.3 ; 14.0) \\
{[129.4 ; 131.7]}\end{array}$ & 1,083 & $\begin{array}{c}114.0(106.0 ; 123.0) \\
{[114.7 ; 116.5]}\end{array}$ & $<0.001$ \\
\hline Diastolic blood pressure & 1,612 & $\begin{array}{c}81.8(74.0 ; 90.0) \\
{[82.8 ; 84.1]}\end{array}$ & 1,083 & $\begin{array}{c}74.0(67.0 ; 81.0) \\
{[74.1 ; 75.4]}\end{array}$ & $<0.001$ \\
\hline BMI $\left(\mathrm{kg} / \mathrm{m}^{2}\right)$ & 1,629 & $\begin{array}{c}25.0(22.0 ; 28.5) \\
{[25.4 ; 25.9]}\end{array}$ & 1,094 & $\begin{array}{c}24.4(21.4 ; 27.5) \\
{[24.7 ; 25.3]}\end{array}$ & $<0.001$ \\
\hline Waist circumference $(\mathrm{cm})$ & 1,614 & $\begin{array}{c}81.0(74.0 ; 90.8) \\
{[82.3 ; 83.4]}\end{array}$ & 1,093 & $\begin{array}{c}76.1(70.0 ; 83.5) \\
{[77.2 ; 78.4]}\end{array}$ & $<0.001$ \\
\hline Waist-to-hip ratio & 1,606 & $\begin{array}{c}0.85(0.80 ; 0.91) \\
{[0.85 ; 0.86]}\end{array}$ & 1,085 & $\begin{array}{c}0.80(0.76 ; 0.84) \\
{[0.80 ; 0.81]}\end{array}$ & $<0.001$ \\
\hline Waist-to-height ratio & 1,629 & $\begin{array}{c}0.53(0.47 ; 0.58) \\
{[0.52 ; 0.53]}\end{array}$ & 1,098 & $\begin{array}{c}0.49(0.45 ; 0.53) \\
{[0.49 ; 0.50]}\end{array}$ & $<0.001$ \\
\hline$\%$ body fat (BIA) & 1,584 & $\begin{array}{c}30.3(24.3 ; 35.7) \\
{[29.5 ; 30.2]}\end{array}$ & 473 & $\begin{array}{c}27.2(21.8 ; 32.6) \\
{[26.7 ; 28.1]}\end{array}$ & $<0.001$ \\
\hline
\end{tabular}

Note: *Mann-Whitney U test. NA: Data not Available; BMI: Body Mass Index; BIA: Bioelectrical Impedance Analysis; $95 \%$ Cl: Confidence Interval of $95 \%$. 
Table 3. Distribution of adiposity indicators and associated variables of maroon women (2008) and mothers of children aged 0 to 5 years (2005). Alagoas, Brazil.

\begin{tabular}{|c|c|c|c|c|c|c|c|}
\hline \multirow{3}{*}{ Variables } & \multirow{3}{*}{ Category } & \multicolumn{4}{|c|}{ Prevalence } & \multirow{3}{*}{$\begin{array}{c}\text { Crude PR }(95 \% \mathrm{Cl}) \\
p\end{array}$} & \multirow{3}{*}{$\begin{array}{c}\text { Adjusted } \mathrm{PR}^{\mathrm{a}}(95 \% \mathrm{Cl}) \\
p\end{array}$} \\
\hline & & \multicolumn{2}{|c|}{ Maroon } & \multicolumn{2}{|c|}{ Mothers } & & \\
\hline & & $\mathrm{n}$ & $\%$ & $n$ & $\%$ & & \\
\hline \multirow[t]{2}{*}{ Stunting $(<150,1 \mathrm{~cm})$} & Yes & 328 & 20.1 & 171 & 15.6 & $1.29(1.09 ; 1.52)$ & $0.99(0.82 ; 1.20)$ \\
\hline & No & 1,301 & 79.9 & 927 & 84.4 & 0.003 & 0.937 \\
\hline \multirow[t]{2}{*}{ Age at menarche (years) } & $\leq 13$ & 606 & 39.1 & 312 & 30.8 & $1.27(1.14 ; 1.42)$ & $1.09(0.96 ; 1.23)$ \\
\hline & $>13$ & 944 & 60.9 & 701 & 69.2 & $<0.001$ & 0.192 \\
\hline \multirow[t]{2}{*}{ Excess weight $\left(\mathrm{BMI} \geq 25 \mathrm{~kg} / \mathrm{m}^{2}\right)$} & Yes & 816 & 50.1 & 483 & 44.2 & $1.13(1.04 ; 1.23)$ & $0.98(0.89 ; 1.07)$ \\
\hline & No & 813 & 49.9 & 611 & 55.8 & 0.003 & 0.634 \\
\hline \multirow[t]{2}{*}{ Hypertension } & Yes & 563 & 34.9 & 123 & 11.4 & $3.07(2.57 ; 3.68)$ & $1.81(1.49 ; 2.21)$ \\
\hline & No & 1,050 & 65.1 & 960 & 88.6 & $<0.001$ & $<0.001$ \\
\hline \multirow[t]{2}{*}{ Body fat (\%) } & $>33$ & 587 & 37.1 & 110 & 23.3 & $1.59(1.33 ; 1.90)$ & $0.93(0.77 ; 1.11)$ \\
\hline & $\leq 33$ & 997 & 62.9 & 363 & 76.7 & $<0.001$ & 0.410 \\
\hline \multirow[t]{2}{*}{ Waist circumference $(\mathrm{cm})$} & $\geq 80$ & 863 & 53.5 & 375 & 34.3 & $1.56(1.42 ; 1.71)$ & $1.23(1.11 ; 1.37)$ \\
\hline & $<80$ & 751 & 46.5 & 718 & 65.7 & $<0.001$ & $<0.001$ \\
\hline \multirow[t]{2}{*}{ Waist-to-height ratio } & $>0.5$ & 996 & 61.1 & 486 & 44.3 & $1.38(1.28 ; 1.49)$ & $1.11(1.02 ; 1.21)$ \\
\hline & $\leq 0.5$ & 633 & 38.9 & 612 & 55.7 & $<0.001$ & 0.015 \\
\hline \multirow[t]{2}{*}{ Waist-to-hip ratio } & $\geq 0.85$ & 786 & 48.9 & 224 & 20.7 & $2.37(2.09 ; 2.69)$ & $1.64(1.43 ; 1.88)$ \\
\hline & $<0.85$ & 820 & 51.1 & 861 & 79.3 & $<0.001$ & $<0.001$ \\
\hline
\end{tabular}

Note: ${ }^{a}$ Adjusted for age; 95\%Cl: Confidence Interval of 95\%; BMI: Body Mass Index; PR: Prevalence Ratio given by the Poisson regression with robust error variance.

and after adjustment, the following variables lost their statistical significance $(p>0.05)$ : stunting, age at menarche $\geq 13$ years, $\mathrm{BMI} \geq 25 \mathrm{~kg} / \mathrm{m}^{2}$, and percentage of body fat $>33 \%$. On the other hand, in the age-adjusted analysis, the prevalences of the following conditions remained higher in maroons: SBP (PR=1.81; $95 \% \mathrm{Cl}: 1.49 ; 2.21)$, WC $\geq 80 \mathrm{~cm}$ ( $\mathrm{PR}=1.23 ; 95 \% \mathrm{Cl}: 1.11 ; 1.37), \mathrm{WHtR}>0.5$ $(\mathrm{PR}=1.11 ; 95 \% \mathrm{Cl}: 1.02 ; 1.21)$, and $\mathrm{WHR} \geq 0.85$ $(P R=1.64 ; 95 \% \mathrm{Cl}: 1.43 ; 1.88)$. Hence, the risk of hypertension was $81 \%$ greater in maroons than in women from the state survey, and the risk of abdominal obesity varied from $11 \%$ to $64 \%$ depending on the indicator used.

\section{DISCUSSION}

This study shows the results of a survey done in 39 maroon communities registered in Alagoas in 2008. All women living in the said communities were eligible for the study, except those who met the exclusion criteria. Hence, the sample is representative of this population. Maroon data were then compared with data from another population-based survey with a probabilistic sample representative of the women with children younger than 5 years living in the State in Alagoas.

The maroon women were in the lowest socioeconomic strata of the country because most $(91.9 \%)$ were in the classes $E$ and $D$. This proportion exceeds that for households in the Brazilian Northeast (63.1\%) by 28.8 percentage points according to data from the National Child and Woman Demography and Health Survey of $2006^{27}$. Although the economic classes of the women in the state survey were unknown, the greater proportion of maroons with low education level and more children indicate higher socioeconomic levels than those of maroons.

According to Ferreira \& Magalhães 7 , approaches that associate obesity with situations of abundance and health lose their explanatory 
power when poor Brazilian females are investigated. The prevalences of excess weight in both maroons and non-maroons were greater than those of underweight in both groups. Similar results were found by Angeli ${ }^{15}$ when she studied 445 women from maroon communities in the Vale do Ribeira in the State of São Paulo. The prevalence of underweight was of only $3.4 \%$, while that of excess weight was of $48.3 \%$.

These results corroborate the data of national surveys of the last two decades, which showed a decrease in the prevalence of underweight and an increase in the prevalence of excess weight ${ }^{28}$. In Alagoas, the nutrition transition process is similar to that of the rest of the country.

Crevelaro $^{29}$ also studied maroon communities in the Vale do Ribeira (São Paulo) to test the hypothesis that changes in nutritional patterns and level of physical activity mainly due to changes in the means of subsistence over the last three decades are increasing the incidence of excess weight. This required assuming the premise that the dietary patterns and levels of physical activity associated with industrialized societies increased the risk of obesity, and that land use restrictions, growth of nearby towns and cities, growth of market economy, and more reliance on remunerated jobs could promote changes in the traditional lifestyles of inhabitants of these communities. She concluded that there is evidence that the studied populations are experiencing a nutrition transition and that females were more affected than males.

In the present study, the prevalence of excess weight was greater in maroons. This may be explained, at least in part, by the higher mean age of the maroon group, because after adjustment for age, the difference seen in the crude analysis lost statistical significance. The same occurred for stunting, age at menarche $\geq 13$ years, and body fat $>33 \%$. Contrary to the variables mentioned above, abdominal obesity indicators and hypertension did not lose significance after adjustment and, therefore, these greater prevalences seen in maroons cannot be justified by age. Nonetheless, the lower strength of the associations after adjustment for age is eye-catching. In the crude analysis, the age difference was reflected in the differences between the variables knowingly associated with ageing and body composition ${ }^{30}$. Bias related to the fact that all women from the state survey had children is unlikely because only a handful of maroons ( $n=41,2.5 \%$ ) did not have children.

Lessa et al. ${ }^{31}$ estimated the prevalence of and the factors associated with hypertension in a sample of adults from Salvador (BA). The total prevalence of hypertension was $29.9 \%$, and in women, the prevalence was $31.7 \%(95 \% \mathrm{Cl}$ : 28.5 to 34.9), which is similar to the prevalence of hypertension in maroons found by the present study (34.9\%). In males and females, the said prevalence was associated with age above 40 years and excess weight, and, in females only, with African ancestry and central obesity.

The cross-sectional nature of the present study prevents the establishment of a cause-andeffect relationship between central obesity and hypertension. However, many studies in the literature suggest that high accumulation of fat in the visceral area is a risk factor for hypertension 20,32. Additionally, reverse causality in this association, i.e., central obesity promoted by hypertension, is hard to conceive.

The mechanisms by which abdominal obesity increases blood pressure have not been completely elucidated. Carneiro et al. ${ }^{32}$ argue that hyperinsulinemia, common in people with central obesity, increases sympathetic nervous system activity and renal tubular sodium reabsorption, factors that increase blood flow to the skeletal muscles, apparently mediated by nitric oxide. These occurrences are markedly low in obese and hypertensive patients with insulin resistance. In addition to this possibly impaired vasodilation, which could further increase blood pressure, the low blood flow to skeletal muscle may also reduce the peripheral uptake of glucose, aggravating insulin resistance. 
It is clear that African-Brazilian populations are at greater risk of central obesity and hypertension ${ }^{11,12,33}$, but the mechanisms that underlie these susceptibilities still need to be explained. Some such studies have stood out, such as those that investigated genetic and environmental factors.

Kimura ${ }^{34}$ studied the genetic component of essential hypertension in a sample of 759 adults from maroon communities in the Vale do Ribeira. She found a significant association between the C825T polymorphism of the gene GNB3 and hypertension. Haplotypic analysis of the variants GNB3 G-350A and GNB3 C825T show that each copy of the C825/G-350 haplotype increases the odds of hypertension by 1.73 times compared with the reference T825/G-350 haplotype. Segregation analysis indicates the existence of a significant association between the GNB3 G-350A polymorphism and essential hypertension. Heritability estimates corroborate the notion that the genetic component of blood pressure is widespread in these populations. Based on these data, she concluded that maroon populations have a polygenic mechanism that regulates blood pressure.

According to Stinson ${ }^{35}$, in 1973 Gleibermann formulated a hypothesis to explain the high rates of hypertension in African Americans based on the idea that a thrifty genotype can become detrimental when the environment changes. The author suggests that a greater ability to retain sodium was selected in Africans as an adaptation to the excessive sweating, common in tropical climates, and low sodium intake because of its low availability in most of Africa. This trait became a disadvantage in regions where sodium is abundant because it further predisposes individuals to hypertension.

Stinson ${ }^{35}$ argues that the epidemiological scenario for these populations probably consists of a complex interaction between population genetics and environmental factors such as diet, poverty, and social discrimination.
The greater prevalence of stunting in maroons found by the present study lost significance after adjustment for age. However, one cannot ignore that the median height of nonmaroon women $(155.5 \mathrm{~cm})$ was smaller than the median height of Brazilian women $(157.5 \mathrm{~cm})^{8}$, women from the Brazilian South $(162.0 \mathrm{~cm})^{8}$, and women surveyed by the WHO-200722 $(163.2 \mathrm{~cm})$, which may stem from intergenerational nutritional deficiencies. In 1989, Alagoas' proportion of chronically malnourished children (height-for-age $<-2$ Z-scores) ranked second in Brazil: $36.8 \%$ vs. $4.9 \%$ in Santa Catarina, state of the Brazilian South with the smallest prevalence of stunting according to the same survey ${ }^{36}$. Stunting in women has been used as an indicator of malnutrition in early life and is an important risk factor for abdominal obesity and hypertension ${ }^{37}$. This risk would stem from metabolic imprinting, a term used to denote the nutritional experience in early life, a critical development period, which may have life-lasting effects and predispose individuals to certain diseases ${ }^{38}$. These effects stem from adaptive mechanisms that improve survival in situations of scarcity. According to Waterland \& Garza $^{38}$, this adaptation would include changes in organ structure, number of cells, and, especially, a more energy-efficient metabolism, resulting in stunted growth and greater ability to store fat. A body thus programmed would have greater chances of surviving malnourishment. On the other hand, this same body would be more susceptible to obesity and chronic, degenerative diseases when exposed to more favorable conditions.

\section{CONCLUSION}

In Alagoas, maroons have lower socioeconomic levels than non-maroons and are at greater risk of abdominal obesity and hypertension, characteristics that classify them as a particularly vulnerable group to the morbidity and mortality caused by cardiovascular diseases, justifying the implementation of specific 
preventive measures and affirmative policies that ensure the rights and quality of life of this population.

\section{COLLABORATORS}

HS FERREIRA helped to conceive the study, coordinate the project, supervise the field work, perform the statistical analyses, and review the article. WO SILVA, EA SANTOS, MKA BEZERRA and BCV SILVA helped to collect data, structure the database, interpret the data, and write the preliminary version of the article. BL HORTA helped to analyze and interpret the data and review the article. All authors approved the final version of the article.

\section{REFERE N CES}

1. Mobley LR, Root ED, Finkelstein EA, Khavjou O, Farris RP, Will JC. Environment, obesity, and cardiovascular disease risk in low-income women. Am J Prev Med. 2006; 30(4):327-32.

2. Ferreira VA, Silva $A E$, Rodrigues $C A$, Nunes $N L$, Vigato TC, Magalhães R. Desigualdade, pobreza e obesidade. Ciênc Saúde Colet. 2010; 15(Supl 1):1423-32.

3. Batista Filho $M$, Rissin, A. A transição nutricional no Brasil: tendências regionais e temporais. Cad Saúde Pública. 2003; 19(Suppl 1):181-91.

4. Tardido AP, Falcão MC. O impacto da modernização na transição nutricional e obesidade. Rev Bras Nutr Clin. 2006; 21(2):117-24.

5. Perozzo G, Olinto MT, Dias-da-Costa JS, Henn RL, Sarriera J, Pattussi MP. Associação dos padrões alimentares com obesidade geral e abdominal em mulheres residentes no Sul do Brasil. Cad Saúde Pública. 2008; 24(10):2427-39.

6. Instituto Brasileiro de Geografia e Estatística. Pesquisa de orçamentos familiares 2002-2003: análise da disponibilidade domiciliar de alimentos e do estado nutricional no Brasil. Rio de Janeiro: IBGE; 2004.

7. Ferreira VA, Magalhães R. Obesidade e pobreza: o aparente paradoxo. Um estudo com mulheres da Favela da Rocinha, Rio de Janeiro, Brasil. Cad Saúde Pública. 2005; 21(Supl 6):1792-800.

8. Instituto Brasileiro de Geografia e Estatística. Pesquisas de orçamentos familiares 2008-2009: antropometria e estado nutricional de crianças, adolescentes e adultos no Brasil. Rio de Janeiro: IBGE; 2010.
9. Instituto de Pesquisa Econômica Aplicada. Comunicados do IPEA: dimensão, evolução e projeção da pobreza por região e por estado no Brasil, n 58. 13 de julho de 2010. Brasília: IPEA; 2010.

10. Urani A. Um diagnóstico socioeconômico do Estado de Alagoas a partir de uma leitura dos dados da pesquisa nacional por amostra de domicílios do IBGE (1992-2004). Maceió: Instituto de Estudos do Trabalho e Sociedade; 2005 [acesso 2012 ago 1]. Disponível em: <http://iets.inf.br/biblioteca/Um_ diagnostico_socioeconomico_do_Estado_de_Alagoas. $p d f>$.

11. Conway JM, Yanovski SZ, Avila NA, Hubbard VS. Visceral adipose tissue differences in black and white women. Am J Clin Nutr. 1995; 61(4):765-71.

12. Torriani M, Grinspoon S. Racial differences in fat distribution: The importance of intermuscular fat. Am J Clin Nutr. 2005; 81(4):731-32.

13. Martins AL. Mortalidade materna de mulheres negras no Brasil. Cad Saúde Pública. 2006; 22(11): 2473-9.

14. Brasil. Fundação Nacional de Saúde. Saúde da população negra no Brasil: contribuições para a promoção da eqüidade. Brasília: Funasa; 2005.

15. Angeli CB. Susceptibilidade genética e outros fatores de risco associados ao sobrepeso e obesidade em populações afro-descententes do Vale da Ribeira/SP [doutorado]. São Paulo: Instituto de Biociências da Universidade de São Paulo; 2008.

16. Brasil. Ministério do Desenvolvimento Social e Combate à Fome. Chamada nutricional quilombola 2006: sumário executivo. Brasília: MDS; 2007.

17. Theodoro M, Jaccoud L, Osório R, Soares S. As políticas públicas e desigualdade racial no Brasil: 120 anos após a abolição. Brasília: IPEA; 2008.

18. Ferreira HS, Lamenha MLD, Xavier Júnior AFS, Cavalcante JC, Santos AM. Nutrição e saúde das crianças das comunidades remanescentes dos quilombos no Estado de Alagoas, Brasil. Rev Panam Salud Pública. 2011; 30(1):51-8.

19. Ferreira HS, Luciano SCM. Prevalência de extremos antropométricos em crianças do estado de Alagoas. Rev Saúde Pública. 2010; 44(2):377-80.

20. Sociedade Brasileira de Cardiologia. VI Diretrizes Brasileiras de Hipertensão. Arq Bras Cardiol. 2010; 95(1 Supl 1):1-51.

21. Lohman TG, Roche AF, Martorel A. Anthropometric standardization reference manual. Champaign: Human Kinetics Books; 1988.

22. World Health Organization. Growth reference height for age girls 5-19 years. Geneva: WHO; 2007 [cited 2012 Aug 1]. Available from: <http://www. who.int/growthref/hfa_girls_5_19years_per.pdf>. 
23. World Health Organization. Obesity: Preventing and managing the global epidemic. Geneva: WHO; 1998. Report of a WHO Consultation on Obesity.

24. Parikh R, Mohan V, Joshi S. Should waist circumference be replaced by Index of Central Obesity (ICO) in definition of metabolic syndrome? Diabetes Metab Res Rev. 2012; 28(1):3-5.

25. Heyward VH, Stolarczyk LM. Avaliação da composição corporal. São Paulo: Manole; 2000.

26. Associação Brasileira das Empresas de Pesquisa. Critério padrão de classificação econômica Brasil/2008. São Paulo: ABEP; 2007.

27. Brasil. Ministério da Saúde. Pesquisa Nacional de Demografia e Saúde da Criança e da Mulher - PNDS 2006: dimensões do processo reprodutivo e da saúde da criança. Brasília: MS; 2009.

28. Instituto Brasileiro de Geografia e Estatística. Pesquisas de orçamentos familiares 2008-2009: antropometria e estado nutricional de crianças, adolescentes e adultos no Brasil. Rio de Janeiro: IBGE; 2010.

29. Crevelaro MA. Transição nutricional em populações quilombolas da mata atlântica: correlações entre os níveis de sobrepeso e obesidade e indicadores socioeconômicos/demográficos em oito comunidades do Vale da Ribeira, São Paulo, Brasil [mestrado]. São Paulo: Universidade de São Paulo; 2009.

30. Grundy SM. Multifactorial causation of obesity: Implications for prevention. Am J Clin Nutr. 1998; 67(Suppl):563S-72S.

31. Lessa I, Magalhães L, Araújo MJ, Almeida Filho N, Aquino E, Oliveira MMC. Hipertensão arterial na população adulta de Salvador (BA) - Brasil. Arq Bras Cardiol. 2006; 87(6):747-56.

32. Carneiro G, Faria NA, Ribeiro FF, Guimarães A, Lerário D, Ferreira SR, et al. Influência da distribuição da gordura corporal sobre a prevalência de hipertensão arterial e outros fatores de risco cardiovascular em indivíduos obesos. Rev Assoc Med Bras. 2003; 49(3):306-11.

33. Okosun IS, Chandra KM, Choi S, Christman J, Dever GE, Prewitt TE. Hypertension and type 2 diabetes comorbidity in adults in the United States: Risk of overall and regional adiposity. Obes Res. 2001; 9(1):1-9.

34. Kimura L. Fatores genéticos associados à hipertensão essencial em populações remanescentes de quilombos do Vale do Ribeira - São Paulo [doutorado]. São Paulo: Universidade de São Paulo; 2010.

35. Stinson S. Nutritional adaptation. Annu Rev Anthropol. 1992; 21:143-70.

36. Monteiro CA. A dimensão da pobreza, da fome e da desnutrição no Brasil. estudos avançados. 1995; 9(24):195-207.

37. Ferreira HS, Florêncio TM, Fragoso MA, Melo FP, Silva TG. Hipertensão, obesidade abdominal e baixa estatura: aspectos de transição nutricional em uma população favelada. Rev Nutr. 2005; 18(2):209-18. doi: 10.1590/S1415-5273200500200005.

38. Waterland RA, Garza C. Potential mechanisms of metabolic imprinting that lead to chronic disease. Am J Clin Nutr. 1999; 69(2):179-97.

Received on: 28/8/2012

Final version on: 30/1/2013

Approved on: 2/5/2013 
